\title{
Intravenous infusion of glucose and insulin in relation to milk secretion in the sow
}

\author{
By L. REYNOLDS AND J. A. F. ROOK* \\ Division of Agricultural Chemistry, School of Agricultural Sciences, \\ University of Leeds, Leeds LS2 $9 \mathfrak{F T}$ \\ (Received ${ }_{5}$ October 1975 - Accepted 10 May I976)
}

\begin{abstract}
I. A comparison was made of the composition of milk from front and rear teats in four sows. There were small and not significant differences in fat, protein and lactose contents, and in the fatty-acid composition of the milk fat with the exception of the $18: 3$ acid where the difference was also small but significant.

2. The effects of intravenous infusions of glucose and insulin in lactating sows on milk secretion and blood composition were investigated in two sows.

3. Intravenous infusion of glucose had no effect on blood plasma glucose concentration but increased the yields of lactose, protein and water.

4. Intravenous infusion of insulin depressed plasma glucose concentration and the yields of lactose and water. The yield of protein was unaffected.

5. It is concluded that differences between the non-ruminant (the sow) and the ruminant in the responses in milk secretion to glucose infusion may be related to differences in the sensitivity to insulin of mammary tissue.
\end{abstract}

Energy undernutrition in the lactating sow is associated with a decrease in milk yield and in milk lactose content but an increase in milk protein and fat contents, although the yields of all three milk constituents are depressed (Rook \& Witter, I968). This preferential effect on lactose secretion is in contrast to the effect of underfeeding in the cow which causes a more marked depression in protein than in lactose yield (Rook \& Line, 1961). In the cow, and in the goat, variation in the concentration of blood plasma glucose within the range $2-4 \mathrm{mmol} / \mathrm{l}$ has little effect, at least in the short term on milk lactose secretion, although at lower concentrations secretion is depressed (Rook \& Wheelock, 1967). There are, however, recognized differences between ruminant and non-ruminant mammary tissues in their sensitivity to insulin (Balmain 8 Folley, 1951) and it appears possible that the sow may differ from the cow in its response to variations in the glucose supply to the mammary gland. An experiment has therefore been undertaken to determine the effect in the sow of intravenous infusions of glucose and of insulin on milk secretion.

Because of the difficulties associated with the removal of milk for analysis from the sow, a preliminary investigation was made of variation in composition of milk from different portions of the udder to determine whether a sample of milk collected from a few teats may be considered representative of the milk of the whole udder.

\footnotetext{
- Present address: The Hannah Research Institute, Ayr KA6 5HL.
} 
EXPERIMENTAL

\section{Animals and their management}

Lactating Landrace $\times$ Large White sows and their litters were selected from the University herd. The sows received daily $2 \mathrm{~kg}$ plus $0.4 \mathrm{~kg} /$ piglet of a standard lactation diet and had free access to water. Litters were adjusted to eight piglets within the Ist week of lactation and creep feed was available to the litter from the 3 rd week post partum. Sows were used for experiments between the 2 nd and 5 th weeks of lactation.

The sows were housed in farrowing units but for the infusion experiment they were transferred to a crate adjacent to, and separated by a movable panel from, another, larger crate in which the piglets were housed.

\section{Experimental design}

Expt I. Comparison of the composition of milk from front and rear teats. Four sows $(846,1033,1037, \mathrm{Jo})$ were used. Milk samples were withdrawn separately from the front two pairs and from the rear two pairs of functional teats.

Expt 2. Effects of intravenous infusions of glucose and insulin on the composition of blood plasma and the yield and composition of milk. Because of the need to give the piglets free access to the sows overnight, difficulty was experienced in maintaining in position for long periods cannulas for the infusion of materials and the withdrawal of blood. Several experiments had to be abandoned and only in two sows (1048, Jo) were the infusions satisfactory and in both of these sows blood samples had to be obtained by incision of the tail.

In both sows glucose and insulin were each infused into each sow for two separate I $\mathrm{d}(24 \mathrm{~h})$ periods, the sequence of infusions being glucose, insulin, glucose, insulin in sow 1048 and insulin, insulin, glucose, glucose in sow Jo. The periods were separated by $\mathrm{I} d, 2 \mathrm{~d}$ and $\mathrm{r} d$ in sow 1048 and by $2 \mathrm{~d}$ in sow Jo. With sow ro 48 , glucose was infused at a rate of $\mathrm{I} O \mathrm{~g} / \mathrm{h}$ and insulin at a rate of ro i.u./h and with sow Jo the corresponding rates were $20 \mathrm{~g}$ glucose and roo j.u. insulin $/ \mathrm{h}$.

On the days on which infusions were given and on the intervening days, and on two preceding and two succeeding days, the daily diet was divided into twenty-four equal portions, and portions were offered at hourly intervals from 08.00 to 18.00 hours, when the remaining portions were given as a single feed. Water was available ad lib. Overnight the piglets had free access to the sow but during the period of hourly feeding they were confined to the separate crate except for access to the sow at hourly intervals. Measurements were made each day throughout the above period. Determinations of milk yield were made over the period $09.00-17.00$ hours. At I 8.00 hours milk was removed for analysis. Samples of coccygeal blood were taken at $2 \mathrm{~h}$ intervals throughout the period of hourly feeding, giving a total of five samples each day.

\section{Techniques}

Infusion procedure. The glucose infusate was prepared as a $5 \circ \mathrm{g} / \mathrm{l}$ solution of glucose which was sterilized by boiling. Solutions of 20 i.u. (sow 1048) and 200 i.u. (sow Jo) 
insulin/100 $\mathrm{ml}$ normal saline $(9 \mathrm{~g} \mathrm{NaCl} / 1)$ were prepared by addition of insulin (B.P. grade, Burroughs Wellcome and Co. Ltd, Temple Hill, Dartford, Kent) to previously sterilized saline solution. The infusates were given as continuous infusions by means of a micro-pump (F. R. Hughes and Co. Ltd, Epsom, Surrey) and passed through a polythene infusion line ( $\mathrm{rmm}$ internal diameter) attached to the back of the sow and connected to a cannula inserted into an ear vein.

Measurement of milk yield. The piglets were removed from the sow at 08.00 hours and returned at $\mathrm{I} h$ intervals to suck. After the Ist feed, the piglets were weighed to the nearest $5 \mathrm{~g}$ before and after sucking. Any urine or faeces voided during sucking was taken up with pre-weighed portions of cotton-wool and the gain in weight of the cotton-wool added to the total weight gain of the litter. Yield measurements were made over eight successive $\mathrm{I} h$ intervals.

Blood plasma. Coccygeal samples of blood were obtained from an incision of the tail and collected in a tube containing heparin; after centrifuging the plasma was removed and used directly or stored at $-20^{\circ}$ until analysed. There is the possibility that plasma composition was affected by excitement during collection of the sample, but every care was taken to keep disturbance to a minimum.

Milk. Milk was removed manually after the intravenous injection of oxytocin $(2-4$ i.u.) into the ear cannula. Milk not required for immediate analysis was stored at $-20^{\circ}$.

\section{Analytical methods}

Blood plasma. Individual samples were analysed for glucose (Huggett \& Nixon, I957) and composite daily samples for amino acids and for total lipids and its fractions by the methods described by Spincer, Rook \& Towers (1969).

Milk. Samples were analysed for dry matter (British Standards Institution, I95I), crude protein $(\mathrm{N} \times 6.38)$ by a Kjeldahl procedure, lactose (British Standards Institution, 1963), fat (British Standards Institution, 1955) and the fatty acid composition of milk fat (Spincer et al. 1969).

\section{RESULTS}

Expt $\mathrm{I}$. Comparison of the composition of milk from front and rear teats. The results for fat, protein and lactose contents and for the fatty acid composition of milk fat are given in Table $\mathrm{r}$. Differences in composition between the milk from front and rear teats were small; the only significant difference was for the content of $18: 3$ acid in milk fat.

Expt 2. Effects of intravenous infusions of glucose and insulin on the composition of blood plasma and the yield and composition of milk. In sow 1048, from the commencement of the 2nd day of glucose infusion, there was a sharp, unexplained reduction in milk yield which persisted for several days irrespective of treatment and the results for the 2nd days of infusion of glucose and insulin have not been reported.

Yields of milk and milk constituents, and milk composition. The results for yield and composition are given in Table 2 and for fatty acid composition of milk fat in Table 3 . In sow 1048 , infusion of glucose was associated with a small $(7 \%)$, non-significant 
Table I. Comparison of the composition of milk from front and rear teats of the mammary gland of sows

\begin{tabular}{|c|c|c|c|}
\hline Component & Front teats & Rear teats & SE \\
\hline $\begin{array}{l}\text { Fat }(\mathrm{g} / \mathrm{kg}) \\
\text { Protein }(\mathrm{g} / \mathrm{kg}) \\
\text { Lactose }(\mathrm{g} / \mathrm{kg})\end{array}$ & $\begin{array}{l}66 \cdot 65 \\
53 \cdot 68 \\
53 \cdot 40\end{array}$ & $\begin{array}{l}66 \cdot 40 \\
53 \cdot 82 \\
53 \cdot 18\end{array}$ & $\begin{array}{l}0.58 \\
0.19 \\
0.18\end{array}$ \\
\hline \multicolumn{4}{|c|}{$\begin{array}{l}\text { Fatty acid composition } \\
\text { of milk fat }(\mathrm{mg} / \mathrm{g})\end{array}$} \\
\hline $14: 0$ & $38 \cdot 6$ & $39 \cdot 3$ & 0.4 \\
\hline $16: 0$ & $299^{\circ}$ & 295.5 & 1.0 \\
\hline $16: 1$ & II 2.9 & III'5 & $1 \cdot 7$ \\
\hline $18: 0$ & $4 \times \cdot 5$ & $40 \cdot 2$ & $2 \cdot 8$ \\
\hline 18:I & $358 \cdot 5$ & $362 \cdot 5$ & 3.6 \\
\hline $18: 2$ & 123.7 & 119.7 & $2 \cdot 6$ \\
\hline $18: 3$ & $\mathrm{I}_{4} \cdot 8$ & $17 \%$ & $0.3^{*}$ \\
\hline
\end{tabular}

Statistical significance of difference between mean values: $* P<0.05$.

increase in milk yield, but with the higher rate of glucose infusion in sow Jo there was a larger, significant $(P<0.05)$ increase of $26 \%$. In association with the increases in milk yield there were increases in the yields of water $(3$ and $28(P<0.05) \%)$, lactose $(5$ and $21 \%$ ), protein $(35$ and $27 \%$ ) and fat ( 46 and $15 \%$ ); variations in lactose content $(-1.4$ and $-2.3 \mathrm{~g} / \mathrm{kg})$ were small but there was a significant $(P<0.05)$ increase in protein content of $1 \mathrm{I} \cdot 4 \mathrm{~g} / \mathrm{kg}$ and in fat content of $24 . \mathrm{Ig} / \mathrm{kg}$ in sow 1048 .

Insulin infusion resulted in a reduction in the yields of milk ( 20 and $22 \%$ ), water $(25$ and $22(P<0.05) \%)$ and lactose $(33$ and $3 \mathrm{I}(P<0.05) \%)$ and in lactose content $(9 . \mathrm{I}$ and $7.8(P<0.0 \mathrm{I}) \mathrm{g} / \mathrm{kg})$. Responses in protein and fat yields were not consistent but, because of the decrease in milk volume, there were increases in the contents of protein $(23.5$ and $13.2 \mathrm{~g} / \mathrm{kg}, P<0.0 \mathrm{I})$ and fat $\left(3 \mathrm{I}^{\cdot} 4(P<0.05)\right.$ and $\left.7.5 \mathrm{~g} / \mathrm{kg}\right)$.

Glucose infusion had little effect on fatty acid composition of milk fat except that the ratio, unsaturated: saturated fatty acids was increased for both $\mathrm{C}_{16}$ and $\mathrm{C}_{18}$ acids. However, insulin infusion increased the ratio, $\mathrm{C}_{16}: \mathrm{C}_{18}$ fatty acids, both saturated and unsaturated, an effect that was especially marked in sow Jo.

Composition of blood plasma. The results are given in Table 4. Blood glucose concentration was not affected significantly by glucose infusion, but there was a distinct decrease $(P<0.01)$ of more than $3 \mathrm{mmol} / 1$ in response to insulin infusion. With glucose infusion, however, there were consistent decreases in the plasma concentrations of triglycerides and of the total essential amino acids (mainly in valine, leucine, phenylalanine, lysine (plus ornithine), histidine and arginine). In contrast, with insulin infusion, there were consistent, but smaller, decreases in the plasma concentrations of triglycerides and consistent decreases in free fatty acids and, in sow Jo; in non-essential amino acids (due mainly to decreases in serine, glutamate, citrulline, proline, glycine and alanine); values for amino acids for sow 1048 are not available. There were no significant effects on the fatty acid composition of the plasma triglycerides. 
Vol. 37




Table 3. Effect of intravenous infusions of insulin and glucose on the fatty acid composition $(\mathrm{mg} / \mathrm{g})$ of milk fat in two sozws

(Mean values with standard error of differences)

\begin{tabular}{|c|c|c|c|c|c|c|c|c|}
\hline \multirow[b]{3}{*}{ Fatty acid } & \multicolumn{4}{|c|}{ Sow I0 48} & \multicolumn{4}{|c|}{ Sow Jo } \\
\hline & \multicolumn{3}{|c|}{ Mean } & & \multicolumn{3}{|c|}{ Mean } & \\
\hline & $\begin{array}{c}\text { Control } \\
(5) \dagger\end{array}$ & $\begin{array}{l}\text { Insulin } \\
\text { (ro i.u./h) } \\
\text { (I)† }\end{array}$ & $\begin{array}{l}\text { Glucose } \\
\text { (Io g/h) } \\
\text { (I)† }\end{array}$ & $\begin{array}{c}\text { SE of } \\
\text { difference }\end{array}$ & $\begin{array}{c}\text { Control } \\
\text { (xo) } \dagger\end{array}$ & $\begin{array}{l}\text { Insulin } \\
\text { (roo i.u./h) } \\
\text { (2) } \dagger\end{array}$ & $\begin{array}{c}\text { Glucose } \\
(20 \mathrm{~g} / \mathrm{h}) \\
(2) \dagger\end{array}$ & $\begin{array}{c}\text { SE of } \\
\text { difference }\end{array}$ \\
\hline I4:0 & $37 \cdot 9$ & $37 \cdot 2$ & $38 \cdot 0$ & $3 \cdot 3$ & $33 \cdot 5$ & $41 \cdot 2^{*}$ & $34: 4$ & $2 \cdot 4$ \\
\hline $16: 0$ & $374 \cdot 4$ & $397 \cdot 7$ & 365.0 & 19.0 & $243 \cdot 1$ & $302 \cdot I * * *$ & $228 \cdot 5$ & I I 3 \\
\hline I6:I & $130^{\circ} \mathrm{I}$ & $134 \cdot 3$ & $146 \cdot 8$ & $7 \cdot 8$ & 118.6 & $167 \cdot 0^{* * * *}$ & $13^{6} \cdot 2 *$ & $7 \cdot 6$ \\
\hline $18: 0$ & $46 \cdot 8$ & $41 \cdot 9$ & 39.7 & $5 \cdot 6$ & $2 I \cdot I$ & 18.2 & 14.0 & $5 \cdot 3$ \\
\hline I8:I & $257 \cdot 4$ & $251 \cdot 5$ & $271 \cdot 0$ & 10.1 & $435 \cdot 3$ & $332 \cdot 3 * * *$ & 430.4 & $\times 3 \cdot 3$ \\
\hline I $8: 2$ & 125.5 & I I 5.5 & I 6.8 & $8 \cdot 4$ & 130.4 & $121 \cdot 6$ & $138 \cdot 8$ & $9 \cdot 1$ \\
\hline I $8: 3$ & $\mathrm{Tr}$ & II.7 & $\operatorname{Tr}$ & $\mathbf{T r}$ & 10.0 & $5 \cdot I$ & $5 \cdot 3$ & 5.9 \\
\hline
\end{tabular}

$\mathrm{Tr}$, trace $(<\mathrm{I} 0)$. Statistical significance of difference between mean values: $P<0.05$; *** $P<0$.00I. The sE of difference quoted applies only to comparisons of control with either insulin or glucose, and the significance levels only to comparisons with the control.

$\uparrow$ Number of daily values on which the mean was based.

Table 4. Effect of intravenous infusion of insulin and glucose on the composition of blood plasma in two sows

(Mean values with standard error of differences)

\begin{tabular}{|c|c|c|c|c|c|c|c|c|}
\hline & & Sow & 1048 & & & Sow & Jo & \\
\hline & & Mean & & & & Mean & & \\
\hline Constituent & $\begin{array}{c}\text { Control } \\
\text { (5)† }\end{array}$ & $\begin{array}{l}\text { Insulin } \\
\text { (Io i.u./h) } \\
\text { (I) } \dagger\end{array}$ & $\begin{array}{c}\text { Glucose } \\
(\mathrm{I} \circ \mathrm{g} / \mathrm{h}) \\
\text { (I)† }\end{array}$ & $\begin{array}{c}\text { SE of } \\
\text { difference }\end{array}$ & $\begin{array}{c}\text { Control } \\
\text { (Io) } \dagger\end{array}$ & $\begin{array}{c}\text { Insulin } \\
(\text { Iooi.u. } / \mathrm{h}) \\
(2) \dagger\end{array}$ & $\begin{array}{c}\text { Glucose } \\
(20 \mathrm{~g} / \mathrm{h}) \\
(2) \dagger\end{array}$ & $\begin{array}{c}\text { SE of } \\
\text { difference }\end{array}$ \\
\hline $\begin{array}{l}\text { Glucose (mmol/l) } \\
\text { Free amino acids } \\
\text { (mg/l) }\end{array}$ & $5 \cdot 67$ & $2 \cdot 44^{* *}$ & $5 \cdot 5 \mathrm{I}$ & 0.45 & $5 \cdot 39$ & $I \cdot 7 I * * *$ & $5 \cdot 14$ & 0.43 \\
\hline Non-essential & 360 & 一 & 359 & 45 & 268 & 163 & 246 & 35 \\
\hline Essential & 246 & - & 230 & 45 & 160 & 158 & I I $* *$ & 12 \\
\hline Triglycerides (mg/1) & 1) $58 \mathrm{I}$ & 466 & 287 & 215 & 749 & 670 & 519 & 134 \\
\hline $\begin{array}{l}\text { Free fatty acids } \\
(\mathrm{mg} / \mathrm{l})\end{array}$ & 70 & 64 & 74 & I9 & I 52 & $80 *$ & I34 & 25 \\
\hline Cholesterol (mg/l) & 108 & 93 & I 15 & 25 & I 44 & 134 & $x_{34}$ & I I \\
\hline Cholesterol esters & 651 & 591 & 615 & 64 & 521 & 549 & 493 & 50 \\
\hline
\end{tabular}

(mg/l)

Statistical significance of difference between mean values: $* P<0.05$; * $P<0.01$; *** $P<0.00 \mathrm{r}$. The SE of difference quoted applies only to comparisons of control with either insulin or glucose, and the significance levels only to comparisons with the control.

$\dagger$ Number of daily values on which the mean was based; the daily values for glucose were the mean of five separate determinations. 


\section{DISCUSSION}

The comparison of the composition of the milk from front and rear teats of the sow suggests that differences in gross composition are negligible and that samples collected from a few teats may be considered representative of the milk of the whole udder. Significant differences between teats in the fat content of milk have been observed by Smith (1952) and by Pond, Van Vleck \& Hartman (1962), but not by Jylling \& Serensen (1960) nor by Duncan \& Garton (1966). Though in the sow, in contrast to the cow, there is no systematic change in fat content throughout a milking (Whittlestone, I952; Jylling \& Sørensen, 1960), there is erratic variation (Perrin, 1954) and this will tend to mask differences between teats. The present results do not permit individual teat comparisons, but they confirm the greater variability for fat than for protein or lactose contents.

The present results for fatty acid composition of milk fat suggest possible systematic variations in 18:3 fatty acids between front and rear teats but the differences are small in relation to variation from other sources and may be ignored.

The most marked and consistent effect of glucose and insulin infusions was on the secretion of lactose and the associated output of water, glucose-promoting and insulindepressing secretion. The relationship between lactose secretion and water output is well established in species other than the sow (Rook \& Wheelock, 1967). Glucose infusion also increased protein secretion. Fat yield was too variable for effects to be demonstrated with certainty, but there were effects on fat composition, glucose infusion increasing the degree of unsaturation and insulin infusion increasing the ratio, $\mathrm{C}_{16}: \mathrm{C}_{18}$ acids.

The effect of insulin infusion on lactose secretion is similar to that observed in the cow and the goat (Rook \& Wheelock, 1967 ). There are, however, differences for the effects of glucose infusion. In the ruminant, glucose infusion has no effect on lactose yield, unless plasma glucose concentration is initially low (Linzell, 1967), and protein yield is unaffected, at least in the short term (Fisher \& Elliot, 1966). Also, whilst glucose infusion $(2-4 \mathrm{~g} / \mathrm{kg}$ body weight per day) increases plasma glucose concentration in the lactating cow (Storry \& Rook, 1965), there was no significant effect in the present experiments at a similar dose rate. Anderson (1974) observed only small increases in peripheral plasma glucose after feeding in adult pigs. In the cow, insulin infusion has no direct effect on lactose secretion and appears to exert its action through the change in plasma glucose concentration (Kronfeld, Mayer, Robertson \& Raggi, I963; Schmidt, 1966). In vitro studies, though, have shown that glucose uptake by non-ruminant mammary tissue is sensitive to insulin, whereas that by ruminant mammary tissue is not (Balmain \& Folley, 195I; Bauman, Ingle, Mellenberger \& Davis, 1973). Glucose infusion in the sow therefore could be expected to increase glucose uptake by the mammary gland in response to an increase in the circulating level of endogenous insulin although there is no appreciable change in the plasma glucose concentration. Whether the associated increase in protein secretion is the result of an increased uptake of glucose by the gland or of a direct action of endogenous insulin 
is not clear but the decrease in plasma concentration of essential amino acids is consistent with an increased synthesis of milk proteins.

Intravenous infusion of insulin in the sow results in effects which differ from those of endogenous insulin, as induced by glucose infusion. There is a substantially lower plasma glucose concentration and (presumably) a higher plasma insulin concentration. The fall in plasma glucose apparently interferes with the effect of insulin on the mammary gland. The hypoglycaemia (or possibly the high insulin concentration) may also affect the secretion of other hormones which increase gluconeogenesis. This may account for the depression of plasma non-essential amino acids following insulin infusion.

The inability to evaluate with certainty the effects on fat yield makes difficult the comparison of effects on fat secretion with those in the ruminant. In the cow, glucose infusion depresses fat yield due to a reduced secretion of $\mathrm{C}_{18}$ fatty acids (Storry \& Rook, I965: Fisher, Elliot \& Corse, I967), whereas in the goat insulin tends to have the opposite effect (Rook \& Hopwood, r970). In the sow, the limited evidence points to an increase, with glucose infusion, in the secretion of fat and $\mathrm{C}_{18}$ fatty acids in spite of a decrease in plasma triglyceride concentration. An increase in milk triglyceride synthesis and secretion could explain the increase in the degree of unsaturation of the milk fatty acids, as an association between desaturation and the rate of triglyceride synthesis has been reported (Kinsella, 1972). The increase in the ratio, $\mathrm{C}_{16}: \mathrm{C}_{18}$ acids in milk fat and the decrease in plasma triglycerides observed with insulin infusion would be consistent with a decrease in the uptake of preformed fatty acids.

We thank Mr T. G. Boaz and Mr A. F. Calder for the supply of animals and the provision of facilities at Leeds University farm, and Dr D. Reid, The Hannah Research Institute, Ayr, for statistical advice.

\section{REFERENCES}

Anderson, D. M. (I974). F. Agric. Sci., Camb. 82, 29.

Balmain, J. H. \& Folley, S. J. (1951). Biochem. F. 49,663.

Bauman, D. E., Ingle, D. L., Mellenberger, R. W. \& Davis, C. L. (1973). F. Dairy Sci. 56, 1520.

British Standards Institution (195I). British Standard no. 174I. London: British Standards Institution.

British Standards Institution (1955). British Standard no. 696. London: British Standards Institution.

British Standards Institution (1963). British Standard no. 1741. 2nd ed. London: British Standards Institution.

Duncan, W. R. H. \& Garton, G. A. (1966). F. Dairy Res. 33, 255.

Fisher, L. J. \& Elliot, J. M. (1966). F. Dairy Sci. 49, 826.

Fisher, L. J., Elliot, J. M. \& Corse, D. A. (1967). F. Dairy Sci. 50, 53.

Huggett, A. St G. \& Nixon, D. A. (ז957). Lancet ii, 368.

Jylling, B. \& Sørensen, P. H. (1960). Arsskr. K. Vet.-Landbohøjsk. p. 20.

Kinsella, J. E. (1972). Lipids 7, 349.

Kronfeld, D. S., Mayer, G. P., Robertson, J. McD. \& Raggi, F. (r963). F. Dairy Sci. 46, 559.

Linzell, J. L. (1967). F. Physiol., Lond. 190, 347.

Perrin, D. R. (1954). 7. Dairy Res. 2I, 55.

Pond, W. G., Van Vleck, L. D. \& Hartman, D. A. (1962). J. Anim. Sci, 21, 293. 
Rook, J. A. F. \& Hopwood, J. B. (I970). F. Dairy Res. 37, I93.

Rook, J. A. F. \& Line, C. (1961). Br. F. Nutr. 15, 109.

Rook, J. A. F. \& Wheelock, J. V. (1967). J. Dairy Res. 34, 273.

Rook, J. A. F. \& Witter, R. C. (1968). Proc. Nutr. Soc. 27, 7 r.

Schmidt, G. H. (1966). F. Dairy Sci. 49, 38 I.

Spincer, J., Rook., J. A. F. \& Towers, K. G. (I969). Biochem. F. III, 727.

Smith, D. M. (1952). Proc. N.Z. Soc. Anim. Prod. 12, 102.

Storry, J. E. \& Rook, J. A. F. (1965). Biochem. F. 97, 879.

Whittlestone, W. G. (1952). J. Dairy Res. 19, 127. 